\title{
Pyrotechnic Mixtures for Production of Gas Generator Charges for Base Bleed Projectiles Based on Ascorbic Acid as an Organic Fuel
}

\author{
Jelena Petković-Cvetković ${ }^{1)}$ \\ Vladimir Milović1) \\ Siniša Pašagić ${ }^{2)}$ \\ Danica Simić ${ }^{1)}$ \\ Ljiljana Jelisavac $^{1)}$ \\ Jovica Nešić ${ }^{1)}$
}

\begin{abstract}
Influence of the composition of pyrotechnic mixtures based on organic fuel (ascorbic acid) on the burn rate, heat of combustion and ignition temperature was examined. Results have shown that all of the tested mixtures meet the quality requirements for application as gas generators for Base Bleed projectiles. The composition of the pyrotechnic mixture with the highest values of heat of combustion and burn rate and the lowest ignition temperature is selected as the most suitable for this application.
\end{abstract}

Key words: Pyrotechnic mixtures, Base Bleed projectile, gas generator, ascorbic acid, burn rate, ignition.

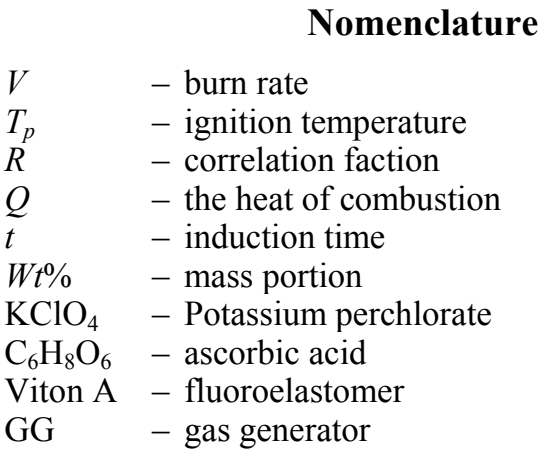

\section{Introduction}

$\mathrm{F}$ IRING ability of military units in field increases with the increase of missile range of the Conventional ammunition , which gives priority to the first attack and provides additional time for proper grouping and better organization of defense or attack.

The resistance that occurs during the flight of projectiles through air affects the reduction of its range. One of the resistance missiles, which is not yet fully optimized, is the resistance of the bottom of the projectile[1-2].

Solution of the problem of reduced-range missiles caused by the resistance of the bottom of the projectile, which has found wide application in all armies of the world, is installation of the gas generator (GG) units at the bottom of the projectile.

Using GG units to increase missile range was exclusively related to installation of the large caliber artillery systems whose charge was largely based on the composite rocket propellant. The outstanding results achieved by installing GG units into the missiles of larger caliber encouraged the thinking that similar solutions could be applied to the antiaircraft ammunition that is currently in use[3].

Previous studies carried out on developing the GG units for $57 \mathrm{~mm}$ projectile were limited to the use of magnesium as a fuel component. An increase up to $20-25 \%$ is observed compared to conventional missiles [4].

Initial tests, carried out on the GG units for $37 \mathrm{~mm}$ projectile (Fig.1), have shown that the mixture, with magnesium as a fuel component, gives very high heat of combustion (there have been melted edges of the aluminum cylinder in which the mixture was pressed) and that during its combustion it released significant amounts of solid and liquid products of combustion. These characteristics of combustion are the advantage of using this mixture for safe ignition composite solid propellant, but it could be a serious drawback to its use in the GG unit Base Bleed projectiles if we take into account the requirements that charging GG unit must satisfy $[5,6]$.

Based on the disadvantage of mixtures based on magnesium as the fuel component, which has been the subject of previous studies, further research is aimed to expand the range of possible fuels for the use in pyrotechnic composition for making the charging unit GG. The advantage of highenergy metal fuels is they have received the organic fuel in its composition that contains a certain amount of oxygen, available for oxidation-reduction unwinding reaction combustion pyrotechnic mixture [1,5-8].

This paper presents the optimization of the composition of pyrotechnic mixture, based on ascorbic acid as an organic fuel for production of gas generators charges for base bleed projectiles.

\footnotetext{
1) Military Technical Institute (VTI), Ratka Resanovića 1, 11132 Belgrade, SERBIA

2) NSPA (NATO Support and Procurement Agency), L-8302 Capellan, LUXEMBOURG

Correspondence to: Jelena Petković-Cvetković; e-mail: jpetkovic82@gmail.com
} 

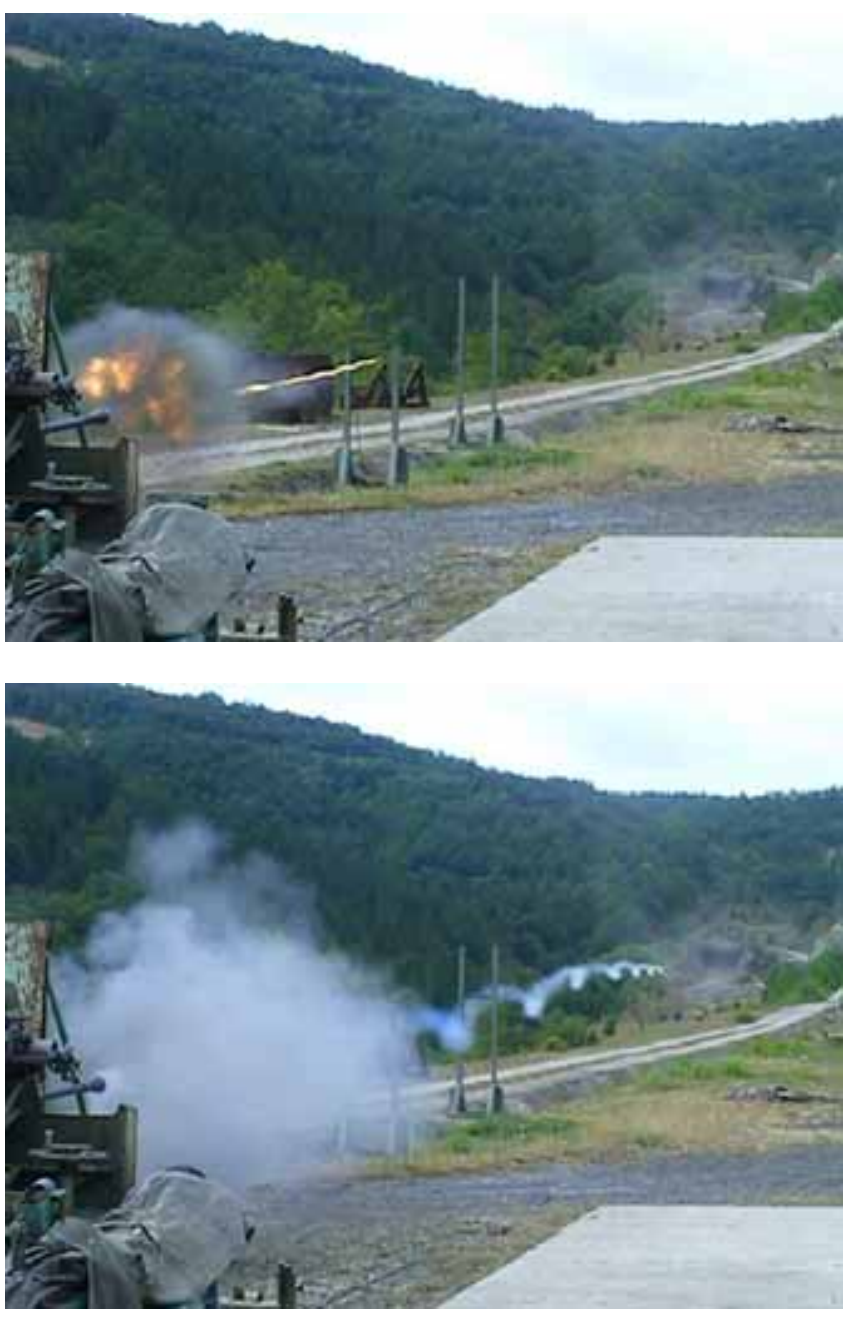

Figure 1. Gas generator units for $37 \mathrm{~mm}$ projectile tests

\section{Experimental part}

\section{Optimization and production of pyrotechnic mixtures}

Optimization of pyrotechnic mixtures was carried out on the basis of the supposed chemical reactions of combustion, in accordance with the reaction oxidation of ascorbic acid $\left(\mathrm{C}_{6} \mathrm{H}_{8} \mathrm{O}_{6}\right)$ and the reaction of decomposition of potassium perchlorate $\left(\mathrm{KClO}_{4}\right)$ [9]. The Viton A is used for binder, in accordance with the optimization of pyrotechnic mixtures.

$$
\begin{gathered}
\mathrm{C}_{6} \mathrm{H}_{8} \mathrm{O}_{6}+5 \mathrm{O}_{2} \rightarrow 6 \mathrm{CO}_{2}+4 \mathrm{H}_{2} \mathrm{O} \\
2,5 \mathrm{KClO}_{4} \rightarrow 2,5 \mathrm{KCl}+5 \mathrm{O}_{2} \\
\mathrm{C}_{6} \mathrm{H}_{8} \mathrm{O}_{6}+2,5 \mathrm{KClO}_{4} \rightarrow 2,5 \mathrm{KCl}+6 \mathrm{CO}_{2}+4 \mathrm{H}_{2} \mathrm{O}
\end{gathered}
$$

The compositions were made in accordance with the adequate quality standards. All components used for composition preparations had a mean particle size smaller than $100 \mu \mathrm{m}$. The mixture ingredients, with their mass portions that were the subjects of investigation in this paper, are presented in Table 1.

Composition $033 / 13 \Pi 1$ is stoichiometric, it has a neutral oxygen balance, if the superior products of combustion in the reaction of combustion are correct. Compositions 034/13П1, 035/13П1 and 036/13П1 are made without a binder component, in order to determine the influence of the binder on the mixture characteristics.
Table 1. Tested pyrotechnic mixtures

\begin{tabular}{|c|c|c|c||}
\hline \multirow{2}{*}{ Sample } & \multicolumn{3}{|c|}{ The mixture ingredients } \\
\cline { 2 - 4 } & $\begin{array}{c}\text { Fuel }(\text { Ascorbic } \\
\left.\text { acid } \mathrm{C}_{6} \mathrm{H}_{8} \mathrm{O}_{6}\right)\end{array}$ & $\begin{array}{c}\text { Oxidizer }(\text { potassium } \\
\left.\text { perchlorate } \mathrm{KClO}_{4}\right)\end{array}$ & $\begin{array}{c}\text { Binder per } 100 \mathrm{~g} \\
\text { mixture } \\
\text { (Viton } \mathrm{A})\end{array}$ \\
\cline { 2 - 4 } & \multicolumn{3}{|c||}{$W t$ of the total mass } \\
\hline \hline $029 / 13 \Pi 1$ & 20 & 80 & 3 \\
\hline $030 / 13 \Pi 1$ & 30 & 70 & 3 \\
\hline $031 / 13 \Pi 1$ & 40 & 60 & 3 \\
\hline $032 / 13 \Pi 1$ & 35 & 65 & $/$ \\
\hline $033 / 13 \Pi 1$ & 33.7 & 66.3 & $/$ \\
\hline $034 / 13 \Pi 1$ & 28 & 72 & $/$ \\
\hline $035 / 13 \Pi 1$ & 30 & 70 & 3 \\
\hline $036 / 13 \Pi 1$ & 32 & 68 & 3 \\
\hline
\end{tabular}

Ascorbic acid $\left(\mathrm{C}_{6} \mathrm{H}_{8} \mathrm{O}_{6}\right)$ is a naturally occurring organic compound with antioxidant properties. It is a white solid, but impure samples can appear yellowish. It dissolves well in water to give mildly acidic solutions. Ascorbic acid is one form ("vitamer") of vitamin C. It was originally called Lhexuronic acid, but when it was found to have vitamin $\mathrm{C}$ activity in animals, the suggestion was made to rename it. The new name, ascorbic acid, is derived from a- (meaning "no") and scorbutus (scurvy), the disease caused by a deficiency of vitamin C (Fig.2).

Ascorbic acid belongs to a group of organic fuels which in its composition contains a certain amount of oxygen. The organic fuel is often used in the manufacture of pyrotechnic mixture when it is necessary, in addition to the release of heat, to provide a substantial amount of gaseous combustion products [3].

Ascorbic acid, as a fuel component, has found a wide application in pyrotechnic mixture for colored smoke mixtures, due to low combustion temperatures of these composition that is high enough to translate the pigment in the state of vapor and yet low enough not to cause its degradation. In these mixtures, the organic fuel is generally combined with the potassium chlorate as an oxidizing agent.

Ascorbic acid belongs to the group of organic fuels, whose general molecular formula is $\mathrm{CxHyOz}$. For thecomplete combustion of these fuels mole it is necessary to $2 x+y$ moles of oxygen atoms (which may be located in the molecule of fuel, freed in an atmosphere in which fuel burns, or originates from an oxidizing agent as other basic components of the pyrotechnic mixture). The complete combustion of one mole of fuel releases $x$ moles of carbon dioxide and $y / 2$ moles of water.

Calculation of the necessary amount of oxygen for combustion of a certain amount of organic fuel is obtained from stoichiometric equations (2).

$$
\mathrm{C}_{6} \mathrm{H}_{8} \mathrm{O}_{6}+5 \mathrm{O}_{2} \rightarrow 6 \mathrm{CO}_{2}+4 \mathrm{H}_{2} \mathrm{O}
$$
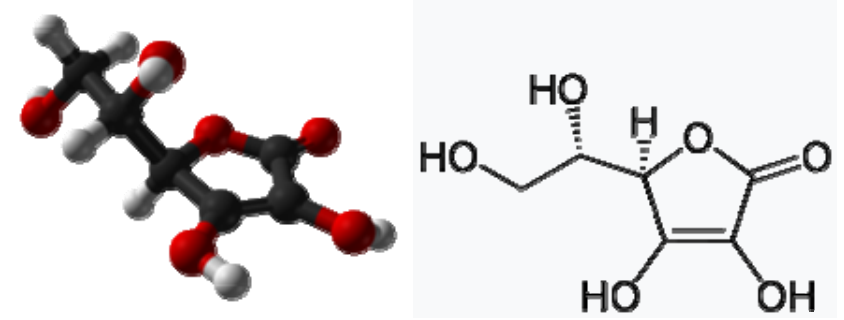

Figure 2. L-Ascorbic acid

Potassium perchlorate (Fig.3) is the inorganic salt with the chemical formula $\underline{\mathrm{KClO}}_{4}$. Like other perchlorates, this salt is a strong oxidizer although it usually reacts very slowly 
with organic substances. This usually obtained as a colorless, crystalline solid is a common oxidizer used in fireworks, ammunition percussion caps, explosive primers, and is used variously in propellants, flash compositions, stars, and sparklers. It has been used as a solid rocket propellant, although in that application it has mostly been replaced by the higher performance ammonium perchlorate. $\mathrm{KClO}_{4}$ has the lowest solubility of the alkali metal perchlorates $(1,5 \mathrm{~g}$ in $100 \mathrm{ml}$ of water at $25^{\circ} \mathrm{C}$ ) [10].

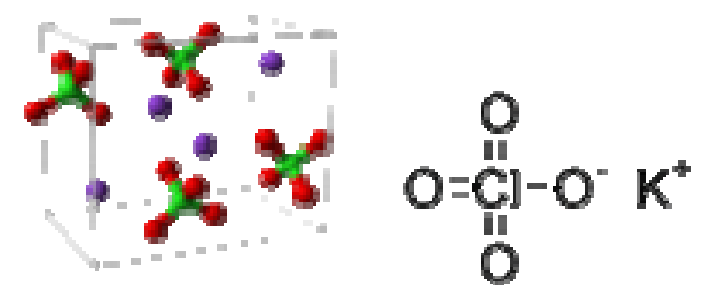

Figure 3. Potassium perchlorate

Viton $\mathrm{A}\left(\left(\mathrm{CH}_{2} \mathrm{CF}_{2}\right)_{\mathrm{n}}\left(\mathrm{CF}\left(\mathrm{CF}_{3}\right) \mathrm{CF}_{2}\right)_{\mathrm{n}}\right)$, a fluoroelastomer is a special purpose fluorocarbon-based synthetic rubber. It has wide chemical resistance and superior performance, especially in high temperature application in different media. This class of elastomers is a family comprising copolymers of hexafluoropropylene (HFP) and vinylidene fluoride (VDF or VF2) [11]. The Viton A, in pyrotechnic mixtures, is used for binder.

\section{Preparation of pyrotechnic mixtures samples for investigation of their burn rate}

The investigation of burn rate was conducted by pressing specific amounts of pyrotechnic mixtures into aluminum alloy tubes (height- $15 \mathrm{~mm}$, radius- $8 \mathrm{~mm}$ and thickness of tube walls- $2 \mathrm{~mm}$ ) with side openings for fiber optic cable at the distance of $8 \mathrm{~mm}$, which is the measuring range for the burn rate. Pressing pyrotechnic elements is performed on the press "DUNKES" in the appropriate tool, at a constant pressure of 200 bar. The mass of pressed formulations into aluminum tubes was measured on a digital scale with a precision $0.001 \mathrm{~g}$ [12]. Charge density was $1.73 \mathrm{~g} / \mathrm{cm}^{3}$.

The combustion time measurements were done using a VOD 811 system, produced by OZM Research, Czech Republic, with specially modified software for the correct display of a lower burn rate. The VOD 811 system is used for detonation and deflagration velocity measurements of explosives and slow burning propellants and pyrotechnic compositions. With a sampling time of 1 nanosecond and a measuring interval between 10 nanoseconds and 50 seconds, the VOD 811 system has proved itself to be a very accurate and reliable device for the conduction of burn rate investigations. For our investigation we have nested the ends of two optic fibers, connected to the VOD 811 system, into specially formed slots in the aluminum tube body, with $8 \mathrm{~mm}$ spacing between them. This spacing represents the measuring range, and with information of the time needed for the combustion zone to pass these two ends of the VOD 811 optic fibers, it is used for the calculation of the burn rate of the composition [13].

\section{Determination of the heat of combustion}

The heat of combustion is defined as amount of heat released through the combustion process of $1 \mathrm{~g}$ of pyrotechnic mixture in the vacuum or in neon or argon atmosphere. Data obtained by calculations of the mixture of the heat of combustion is based on the anticipated chemical reactions since the whole range of possible parallel reactions is almost impossible to define. Therefore, it is used only for orientation purposes [9]. Precise heat of combustion data for a specific mixture is gained through investigations in specialized appliances in accordance with the methodology defined in [14].

In determining the heat of combustion it is important that the weight of the sample pyrotechnic mixture sufficient to increase the temperature of water in the calorimeter court is not less than $0.3^{\circ} \mathrm{C}$. In order to obtain reliable and reproductive results, in addition to this requirement, it is necessary to identify and select the environment in which the pyrotechnic mixture will be burned, and the form of the sample pyrotechnic mixture which can be loose or pressed. The sample pyrotechnic mixture for testing the heat of combustion consisted of $3 \mathrm{~g}$ pyrotechnic mixture, in a loose form.

The IKA C-2000 Isoperibolic calorimeter, fitted with the C5010 decomposition vessel was used for the measurements of the heat of combustion in this investigation [15].

\section{Testing of the ignition temperature}

Ignition temperature represents a temperature value at which a specific composition instantly ignites. The investigation method consists of a thermal block preheated to a specific temperature, with a hole in it for placing the composition to be investigated, and a control unit used to preset the investigation temperature and the heating method. The induction time represents the time period from the moment a mixture is placed into the thermal block to the moment it ignites. The mixture that is to be tested is in a loose form [16].

Ignition temperature is determined to compile $029 / 13 \Pi 1$, 030/13П1, 032/13П1 and 033/13П1. The unit mixes weighing individually the timing of induction was a small scoop $(\approx 0,05 \mathrm{~g})$. To obtain data that are more precise for the calculation of ignition temperature, five measurements for each of the minimum three investigating temperatures are required. The induction time of all measurements has to be between $2 \mathrm{~s}$ and $11 \mathrm{~s}$.

\section{Results and discussion}

\section{Heat of combustion}

Table 2 shows the values of heat of combustion for tested samples.

Table 2. The heat of combustion of the pyrotechnic mixture

\begin{tabular}{|c|c|c|}
\hline Sample & $\begin{array}{c}\text { Composition mixture (fuel / oxi- } \\
\text { dizer / binder) Wt \% }\end{array}$ & $\mathrm{Q}[\mathrm{J} / \mathrm{g}]$ \\
\hline \hline $029 / 13 \Pi 1$ & $20 / 80 / 3$ & 3542.6 \\
\hline $034 / 13 \Pi 1$ & $28 / 72$ & 4243.1 \\
\hline $030 / 13 \Pi 1$ & $30 / 70 / 3$ & 4570.7 \\
\hline $036 / 13 \Pi 1$ & $32 / 68$ & 4519.2 \\
\hline $033 / 13 \Pi 1$ & $33.7 / 66.3 / 3$ & 4247.4 \\
\hline $032 / 13 \Pi 1$ & $35 / 65 / 3$ & 4178.5 \\
\hline $031 / 13 \Pi 1$ & $40 / 60 / 3$ & 3671.4 \\
\hline $035 / 13 \Pi 1$ & $30 / 70$ & 4541.0 \\
\hline
\end{tabular}

As previously mentioned, the compositions $034 / 13 \Pi 1$, 035/13П1 and 036/13П1 do not include binder component in order to determine the influence of the binder on the characteristics of the pyrotechnic mixture. Samples 030/13П1 and $035 / 13 \Pi 1$ have the same ratio fuel/oxidant. The values of the heat of combustion of listed mixture are almost the same, and the influence of $3 \%$ binder to the characteristics of the mixture can be ignored.

The dependence of the heat of combustion of the content of ascorbic acid is shown in Fig.1. 


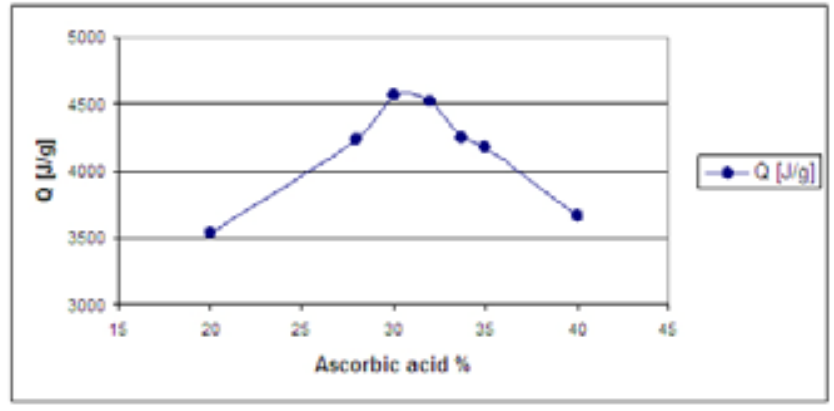

Figure 4. The dependence of the heat of combustion on ascorbic acid content

Analysis of the results in Table 2 and in Fig.4 shows that a pyrotechnic mixture $30 / 13 \Pi 1$ has the highest heat of combustion, while the value of the heat of combustion for other pyrotechnic mixture decreases with increasing (i.e. reducing) mass fraction of ascorbic acid.

It can be said that the composition $30 / 13 \Pi 1$, the mass ratio of components 30/70 (fuel/oxidizer), has a stoichiometric ratio of reactants. To this mixture at the temperature of pyrotechnic mixture combustion, the combustion products are most likely not those supposed by reaction (1).

\section{Burn rate}

Results of determining the burn rate are presented in Table 3.

Table 3. Burn rate

\begin{tabular}{|c|c|c|}
\hline Sample & $\begin{array}{c}\text { Composition mixture } \\
W t \%\end{array}$ & $V[\mathrm{~mm} / \mathrm{s}]$ \\
\hline \hline $29 / 13 \Pi 1$ & $20 / 80 / 3$ & 0.90 \\
\hline $30 / 13 \Pi 1$ & $30 / 70 / 3$ & 1.85 \\
\hline $31 / 13 \Pi 1$ & $40 / 60 / 3$ & Hardly ignitable mixture \\
\hline $32 / 13 \Pi 1$ & $35 / 65 / 3$ & 1.76 \\
\hline $33 / 13 \Pi 1$ & $33.7 / 66.3 / 3$ & 2.05 \\
\hline
\end{tabular}

The obtained values of the burn rate are between $0,9 \mathrm{~mm} / \mathrm{s}$ and $2.05 \mathrm{~mm} / \mathrm{s}$; it is expected for this type of pyrotechnic composition and they fulfill the requirements [7] that the burn rate of gas generators charging for Base Bleed projectile is less than $2 \mathrm{~mm} / \mathrm{s}$ [17].

During the examination it has been noticed that the pyrotechnic mixture $031 / 13 \Pi 1$ is hardly flammable, probably due to high content of fuels ( $40 \mathrm{wt} \%$ ), so it is excluded from further research.

Fig. 5 gives a graphical representation of changes in the value of the burn rate as a function of content of fuel.

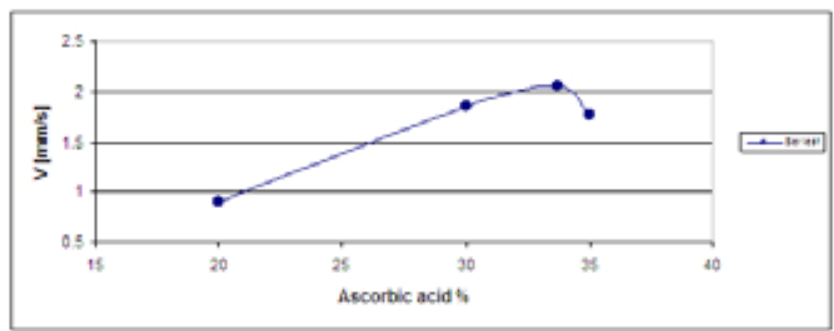

Figure 5. The burn rate as a function of the mass fraction of fuel

From the analysis of the test results of the burn rate (Table 3 ) and depending on the burn rate of the contact of fuels in pyrotechnic mixture it can be seen that a mixture of $033 / 13 \Pi 1$, with the assumed stoichiometric composition of the reaction (1), has a maximum burn rate.

The maximum of the curve which represents dependence of the burn rate and composition of pyrotechnic mixture is relatively shifted compared to the maximum of the curve that represents dependence of the heat of combustion and the composition of the pyrotechnic mixture, but the trend is the same. Because the burn rate depends on several different factors [18], it is assumed that the effect of the heat conduction layer (aluminum tube), which is significantly higher than the thermal conductivity of the mixture with organic fuel, is dominant.

\section{Ignition temperature}

The induction time and the ignition temperature measured for the compositions chosen for a more detailed analysis are shown in Tables 4 and 5 and graphically presented in Figures 6-9.

Table 4. Induction time

\begin{tabular}{|c|c|c|c|c|c|c|c|}
\hline \multirow{2}{*}{ Sample } & & \multicolumn{6}{|c|}{$T\left[{ }^{\circ} \mathrm{C}\right]$} \\
\hline & & 450 & 480 & 500 & 520 & 530 & 540 \\
\hline "029/13П1 & \multirow{4}{*}{$t,[\mathrm{~s}]$} & 21.15 & $\overline{~ / 1}$ & 10.79 & 7.31 & 6.84 & 4.02 \\
\hline 030/13П1 & & 22.96 & & 13.48 & 7.57 & 6.07 & 1.59 \\
\hline 032/13П1 & & 21.15 & 15.99 & 10.28 & 5.87 & 3.7 & 1 \\
\hline 033/13П1 & & 24.98 & I & 10.48 & 7.29 & 5.26 & 3.21 \\
\hline
\end{tabular}

The induction time dependence on temperature (shown in Figures 3 to 6) can be approximated by linear functions of the form $y=k x+n$.

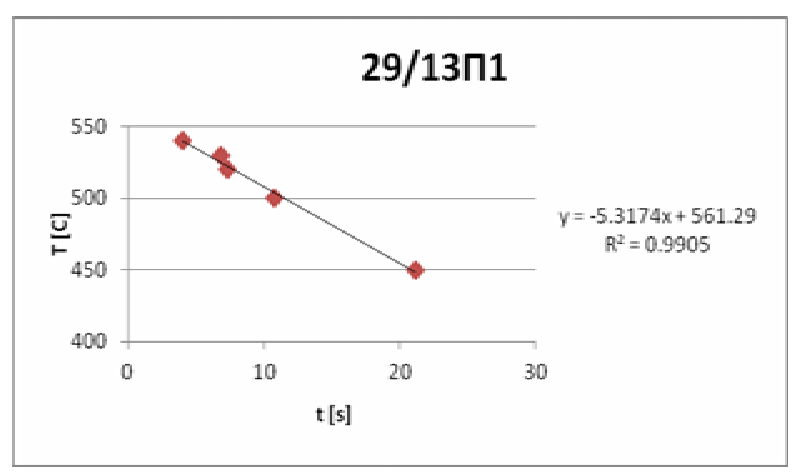

Figure 6. The induction time dependence on temperature of the mixture 029/13П1

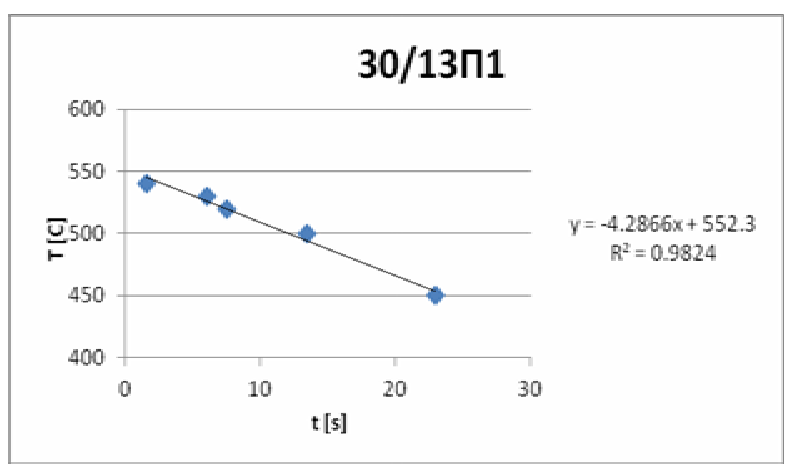

Figure 7. The induction time dependence on temperature of the mixture $030 / 13 \Pi 1$

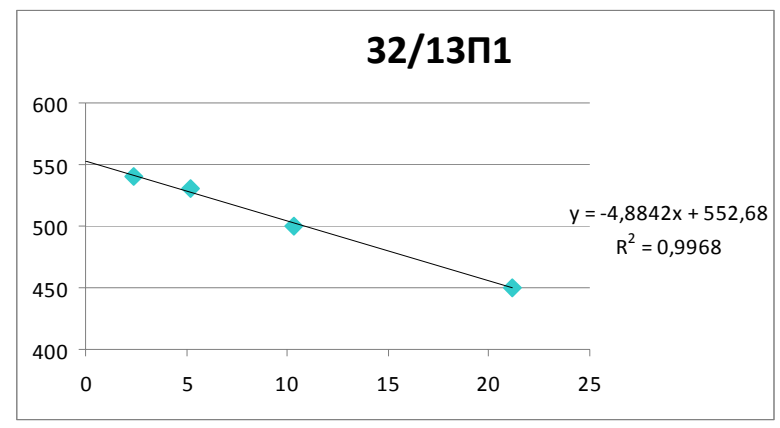

Figure 8. The induction time dependence on temperature of the mixture $032 / 13 \Pi 1$ 


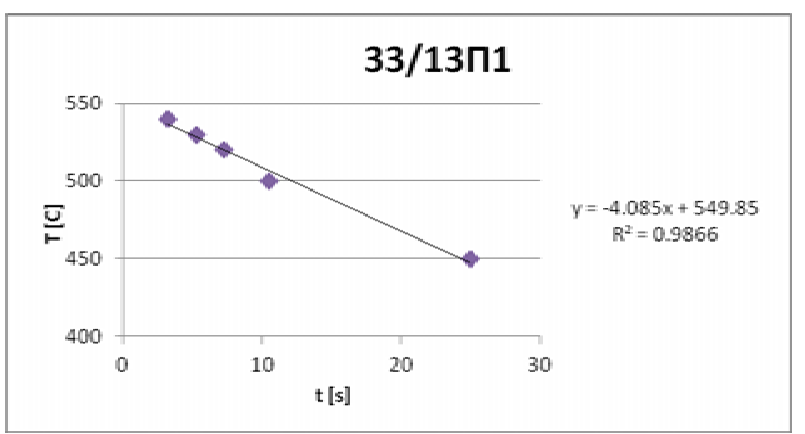

Figure 9. The induction time dependence on temperature of the mixture $033 / 13 \Pi 1$

Line equation with the appropriate factor correlations $\left(R^{2}\right)$ and the calculated value of the ignition temperature during induction $t=0$ are shown in Table 5 .

Table 5. The equation of the correlation factor and the ignition temperature

\begin{tabular}{||c|c|c|c||}
\hline Sample & Line equation & $R^{2}$ & $T_{p},\left[{ }^{\circ} \mathrm{C}\right]$ \\
\hline \hline $029 / 13 \Pi 1$ & $\mathrm{y}=-5.3174 \mathrm{x}+561.29$ & 0.9905 & 561 \\
\hline $030 / 13 \Pi 1$ & $\mathrm{y}=-4.1752 \mathrm{x}+549.59$ & 0.9835 & 549 \\
\hline $032 / 13 \Pi 1$ & $\mathrm{y}=-4.8842 \mathrm{x}+552.68$ & 0.9968 & 553 \\
\hline $033 / 13 \Pi 1$ & $\mathrm{y}=-4.085 \mathrm{x}+549.85$ & 0.9866 & 550 \\
\hline
\end{tabular}

The ignition temperatures are following the trend of other features of the pyrotechnic mixture. The lowest value of the ignition temperature is obtained for a sample of $30 / 13 \Pi 1$, which is another confirmation of stoichiometric composition of the pyrotechnic mixture.

\section{Conclusion}

The pyrotechnic compositions are defined and tested with organic fuel, for production of charging gas generators for Base Bleed projectiles. Based on the analysis of test results it can be concluded:

- The obtained values of the burn rate are between $0,9 \mathrm{~mm} / \mathrm{s}$ and $2,05 \mathrm{~mm} / \mathrm{s}$ as it is to be expected for this type of pyrotechnical composition. The requirements [9], that the burn rate of gas generators composition for Base Bleed projectile is less than $2 \mathrm{~mm} / \mathrm{s}$, are fulfilled.

- Pyrotechnic composition 30/13П1 has the highest value of heat of combustion. The values of the heat of combustion for other tasted pyrotechnic mixtures decrease with increasing (i.e. reducing) content of ascorbic acid. It can be concluded that the composition of 30/13П1 mass ratio of components 30/70 (fuel/oxidizer) has a stoichiometric ratio.

- The curve of dependence of the burn rate and the composition of the pyrotechnic mixture follows the trend of the curve depending on the heat of combustion of the composition, provided that the maximum of this curve is moved relative to the stoichiometric composition.

- Samples 030/13П1 and 035/13П1 have the same ratio fuel/oxidant, but the sample $030 / 13 \Pi 1$ is with $3 \%$ binder. The values of the heat of combustion of listed mixture are almost the same, and the influence of $3 \%$ binder to the characteristics of the mixture can be ignored.

- The ignition temperature follows the trend of other characteristics of pyrotechnic mixtures. The lowest value has a mixture of $30 / 13 \Pi 1$, which is another confirmation of the stoichiometric composition of this mixture.

\section{References}

[1] SUBOTIĆ,Z., JARAMAZ,S.: Report on Constructional Investigations of Experimental Pieces of Gas Generator for $152 \mathrm{~mm}$ M-84 HEAT Base Bleed Projectiles, MTI, TI-02-01-0238, Belgrade, 1989.

[2] INJAC,M.: Spoljnobalističke mogućnosti povećanja dometa artiljerijskih projektila $130 \mathrm{~mm}$ i $152 \mathrm{~mm}$ primenom gasogeneratora, TI-02-27-116, Beograd, 1984.

[3] GREENE,R.W.: Solid pyrotechnic compositions for projectile base bleed systems, United States Patent 5056436, 1991.

[4] YONG,L.V., SMIT,K.J.: A theoretical study of the combustion of Magnesium/Teflon/Viton pyrotechnic compositions, MRL-TR-91-25, 1991.

[5] PAŠAGIĆ,S.: Pirotehničke smeše za izradu punjenja gasogeneratora base bleed projektila, VTI, TI-003-01-0557, Beograd, 2009.

[6] PAŠAGIĆ,S.: Ispitivanje funkcionalnih karakteristika odabranih pirotehničkih smeša za izradu punjenja gasogeneratora Base Bleed projektila, VTI, TI-004-01-0614, Beograd, 2010.

[7] PAŠAGIĆ,S.: Pirotehnička punjenja gasogeneratora Base Bleed projektila na bazi organskih komponenata, VTI, TI-004-01-0658, Beograd, 2011.

[8] PAŠAGIĆ,S., PETKOVIĆ,J.: Organic substances in production of gas generator pyrotechnic charges, Military Technologies and Systems Conference, December 2011, BULGARIA

[9] CONKLING,J.A., MOCELLA,C.: Chemistry of Pyrotechnics - Basic Principles and Theory, $2^{\text {nd }}$ ed., CRC Taylor \& Francis Group, 2011.

[10] BAKER,J.T.: Potassium Perchlorate MSDS, 2007-02-16. Retrieved 2007-12-10.

[11] www.wikipedia.org/wiki/fluoroelastomer

[12] BOŠNJAKOVIĆ,M.: Osvajanje postupka merenja brzine gorenja pirotehničkih sastava, VTI, TI-277, Beograd, 1973.

[13] PAŠAGIĆ,S, ANTONOVIĆ,D, SIROVATKA,R, PETKOVIĆ,J.: Influence of copper wire heat guides on the combustion velocity of organic based charges for gas generator of base bleed projectiles, Central European Journal of Energetic Materials, ISSN 1733-7178, 2015, Vol.12, No.3, pp.563-557.

[14] STANKOVIĆ,M.: IS-042104, Interni standard za kalorimetrijsko ispitivanje eksplozivnih materija, 1992.

[15] [15] PAŠAGIĆ,S.: Investigation of Pyrotechnic Charges for Base Bleed Projectiles, Scientific Technical Review, ISSN 1820-0206, 2011, Vol.61, No.3-4, pp.56-62.

[16] BOŠNJAKOVIĆ,M.: Osvajanje postupka merenja temperature paljenja i vremena indukcije, VTI, TI-320, Beograd, 1974.

[17] PAŠAGIĆ,S., PETKOVIĆ,J.: Usage of organic substances as fuels in production of gas generator pyrotechnic charges for Base Bleed projectiles, 4th International Scientific Conference on Defensive Technologies OTEX 2011, 06-07. October 2011, Belgrade, SERBIA, ISBN978-86-81123-50-8, pp.349-353.

[18] PETKOVIĆ,J.,: Pirotehničke smeše na bazi organskih goriva za izradu punjenja gasogeneratora base bleed projektila, VTI, TI-VTI 04-010791, Beograd, 2013. 


\title{
Pirotehničke smeše za punjenje gasogeneratora Base Bleed projektila na bazi askorbinske kiseline kao organskog goriva
}

\begin{abstract}
Ispitan je uticaj sastava pirotehničkih smeša na bazi organskog goriva (askorbinska kiselina) na linearnu brzinu sagorevanja, energetski potencijal i temperaturu samozapaljenja. Dobijene vrednosti linearne brzine sagorevanja svih ispitanih pirotehničkih smeša zadovoljavaju zahtev za punjenje gasogeneratora Base Bleed projektila. Definisan je sastav pirotehničke smeše sa najvećim energetskim potencijalom, brzinom sagorevanja i najnižom temperaturom samozapaljenja kao najpogodniji za ovu primenu.
\end{abstract}

Ključne reči: pirotehničke smeša, projektil sa gasogeneratorom (Base Bleed), generator gasa, askorbinska kiselina, brzina sagorevanja, samopaljenje.

\section{Пиротехнические смеси ДЛЯ заполнения газогенераторов Base Bleed снаряда на основе аскорбиновой кислоты в качестве органического топлива}

\begin{abstract}
Здесь определено влияние состава пиротехнических смесей на основе органического топлива (аскорбиновая кислота) на линейную скорость горения, энергетический потенциал и температуру воспламенения. Результаты показали, что все полученные значения линейной скорости горения всех испытанных пиротехнических смесей отвечают требованиям для зарядки газогенераторов Base Bleed снарядами. Наиболее подходящим для этого применения выбран и определён состав пиротехнической смеси с наибольшим энергетическим потенциалом и скоростью горения и самой низкой температурой воспламенения.
\end{abstract}

Ключевые слова: пиротехническая смесь, снаряд с газогенератором (Base Bleed), газогенератор, аскорбиновая кислота, скорость горения, воспламенение.

\section{Les mélanges pyrotechniques pour la charge de générateur de gaz du projectile Base Bleed basés sur l'acide ascorbique comme le carburant organique}

\footnotetext{
L'influence de la composition des mélanges pyrotechniques basés sur le carburant organique (acide ascorbique) sur la vitesse linéaire de combustion, le potentiel énergétique et la température de l'ignition spontanée a été examiné. Les valeurs obtenues pour la vitesse linéaire de combustion de tous les mélanges pyrotechniques examinés satisfont l'exigence pour la charge du générateur de gaz du projectile Base Bleed. On a défini la composition du mélange pyrotechnique avec le plus grand potentiel énergétique, la vitesse de combustion et la plus basse température de l'ignition spontanée comme la plus propice pour cette application.
}

Mots clés: mélange pyrotechnique, projectile à générateur de gaz (Base Bleed), générateur de gaz, acide ascorbique, vitesse de combustion, ignition spontanée. 